\title{
Temperature distribution analysis of different technologies of PV modules using infrared thermography
}

\author{
Slawomir Gulkowski ${ }^{1, *}$, Natalia Zytkowska ${ }^{2}$, and Piotr Dragan ${ }^{3}$ \\ ${ }^{1}$ Institute of Renewable Energy Engineering, Faculty of Environmental Engineering, Lublin \\ University of Technology, Nadbystrzycka 40B, 20-618 Lublin, Poland \\ ${ }^{2}$ Student Research Group 'Grupa Ogniwo', Faculty of Environmental Engineering, Lublin University \\ of Technology, Nadbystrzycka 40B, 20-618 Lublin, Poland \\ ${ }^{3}$ Faculty of Environmental Engineering, Lublin University of Technology, Nadbystrzycka 40B, \\ 20-618 Lublin, Poland
}

\begin{abstract}
Photovoltaic systems are designed to operate for a very long time according to the modules' warranty that guarantees at least of $80 \%$ of the nominal power production after 20 years of use. In order to assure the continuous power production with a high level for a long time, thermographic analysis should be performed to detect incipient anomalies in individual modules and junction boxes. This safe, convenient and noncontact method allows carrying out the inspection for working system without any contact with live wiring and without disconnecting the PV systems. Temperature distribution of the module surface can reveal many different types of anomalies, i.e. hot spots caused by local shading, microcracking or cell breakage. This paper shows the results of the infrared thermography analysis of the operating PV systems consisting of different technological modules: polycrystalline silicon ( $\mathrm{pc}-\mathrm{Si}$ ), copper indium gallium diselenide (CIGS) and cadmium telluride (CdTe). The average working temperature of each different kind of technological module as well as overheated areas were investigated in this study. Temperature of the MC4 connectors was also analysed.
\end{abstract}

\section{Introduction}

The area of commercial solar cells ranges from $100 \mathrm{~cm}^{2}$ (4 inch wafer) to $225 \mathrm{~cm}^{2}$ (6 inch wafer). Such small devices can produce under standard test conditions (STC) about $0.6 \mathrm{~V}$ and current ranging from $3 \mathrm{~A}$ to even $8.5 \mathrm{~A}$ depending on the wafer size. In order to reach higher values of voltage, solar cells have to be connected in series inside the photovoltaic module. Series-connected solar cells increase the output voltage and thus output power of the PV module. However, the current in such a configuration depends on the weakness of the cells. For this reason using the PV module inappropriately can lead to many problems that should be detected in a very early stage in order to prevent serious damage of the

* Corresponding author: s.gulkowski@pollub.pl 
module. Common problems that can occur in photovoltaic installations were pointed out in paper [1] according to the international standards and monitoring procedures described in Reports of $[2,3]$. The main problem for PV systems is shading for various reasons: buildings, trees, or small objects in the area of installation. In the case of ground-mounted installations a very common problem is shading caused by plants. Even small shade over the PV module leads to a high drop of the energy production and sometimes even to damage of the module. The most dangerous are shades that cover only smart parts of the module, for example bird droppings, leaves, dirt on the edges $[1,4]$. Shaded parts work with higher temperature than rest of the module. It leads to hot-spots - a well known phenomena in photovoltaic applications [5]. The background to hot-spot phenomena is that the shaded cell dissipates power that is generated by the surrounding solar cells in a form of heat. As a result, it behaves more like a load than a power generator. The works of [6,7] summarise the reasons for degradation and failure of silicon crystalline modules that were working in the USA up to three years. As it was shown, $22 \%$ of the all failures were caused by the hot-spots. For this reason many researchers focus on the hot-spot detection methods [8-10]. Another group of faults contains problems connected with the production process that depends on the technology of the module [11-15]. Very common faults are optical degradation or discoloration that are caused by a poor quality lamination process. Faults known as cell crack, snail trails, broken busbars together with optical problems were described in detail in the paper of [16].

In order to detect the faults mentioned above, a non-destructive, fast and relatively inexpensive infrared (IR) thermography technique can be used. Under appropriate weather conditions, the IR thermography detection method allows obtaining the image of the modules with the information of temperature distribution which is uniform for a nondamaged device. Any fault connected to a higher temperature of the module can be detected as an irregularity in this uniform distribution of temperature [16-21].

This paper shows the results of IR thermography analysis of a $1.4 \mathrm{MW}$ power plant located in eastern Poland that was carried out during fully sunny days of summer under an irradiance level higher than $900 \mathrm{~W} / \mathrm{m}^{2}$. Polycrystalline silicon (pc-Si) as well as thin film modules (CdTe and CIGS) were examined. Temperature distribution of all modules of the PV power installation was examined. Hot-spots caused mostly by plants were detected. The temperature of the connectors was also measured.

\section{Materials and methods}

Poland is located in a moderate climate zone. The annual density of solar radiation ranges between $950 \mathrm{kWh} / \mathrm{m}^{2}$ and $1150 \mathrm{kWh} / \mathrm{m}^{2}$. Most energy reaches the surface between April and September. Lublin province exhibits the best solar conditions in comparison with the rest of the country. For this reason, higher interest of investments in photovoltaic installations has been noticed in this area in the last few years.

The analysed PV installation of $1.4 \mathrm{MWp}$, located in Zielawa Valley (N 51 $50^{\prime}$ and E $23^{\circ} 09^{\prime}$ ) is consider as the largest PV system in this region of Poland (Fig. 1). Zielawa Valley power plant started in November 2014, and after one year of working it produced more than 1.5 MWh of energy [22]. It was also the first such large installation in the Lublin province. The majority of the system consists of polycrystalline modules (5560 items) with a total capacity of $1.4 \mathrm{MWp}$. However, it also includes an experimental part consisting of CIGS modules (24 items), CdTe modules (44 items) and a-Si modules (36 items) with a total capacity of $10.5 \mathrm{kWp}$. The PV farm covers the area of $3.5 \mathrm{ha}$, while the area of all $\mathrm{PV}$ modules is equal to $0.87 \mathrm{ha}$. Table 1 presents the technical specification of modules under study installed on the PV power plant. 


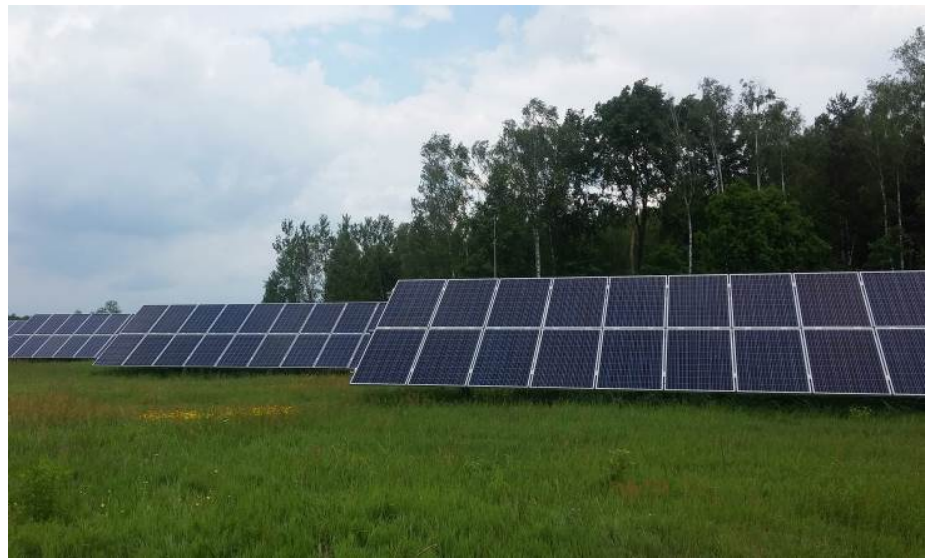

Fig. 1. Photovoltaic power plant of Zielawa Valley [the authors' archive].

Table 1. Specification of PV modules installed in Zielawa Valley power plant [23-25].

\begin{tabular}{|c|c|c|c|c|c|c|}
\hline No & Technology & Capacity & Efficiency & $\begin{array}{c}\text { Temperature } \\
\text { coefficient }\end{array}$ & Items & $\begin{array}{c}\text { Total } \\
\text { capacity }\end{array}$ \\
\hline$[-]$ & {$[-]$} & {$[\mathrm{Wp}]$} & {$[\%]$} & {$[\% / \mathrm{K}]$} & {$[-]$} & {$[\mathrm{kWp}]$} \\
\hline 1 & $\mathrm{pc}-\mathrm{Si}$ & 250 & 15.4 & -0.4 & 5560 & 1390 \\
\hline 2 & $\mathrm{CIGS}$ & 155 & 12.6 & -0.31 & 24 & 3.72 \\
\hline 3 & $\mathrm{CdTe}$ & 75 & 10.6 & -0.25 & 44 & 3.3 \\
\hline
\end{tabular}

All modules of different technology were examined with the use of infrared thermography camera of Flir System of type T620BX. A temperature distribution study of modules and connectors has been obtained. The observations were carried out during a sunny summer day under full insolation. The irradiance level was found to be between $900 \mathrm{~W} / \mathrm{m}^{2}$ and $1000 \mathrm{~W} / \mathrm{m}^{2}$ during the measurements. Datasheet specification of the IR-camera is shown in Table 2.

Table 2. Technical specification of the IR-camera by Flir Systems type T620BX [26].

\begin{tabular}{|c|c|}
\hline IR resolution & $640 \mathrm{x} 480$ pixels \\
\hline Thermal sensitivity/NETD & $<40 \mathrm{mK} @+30^{\circ} \mathrm{C}\left(+87^{\circ} \mathrm{F}\right)$ \\
\hline Zoom & $1-4 \mathrm{x}$ continuous, digital zoom \\
\hline $\begin{array}{c}\text { Focal Plane Array (FPA) } / \\
\text { Spectral range }\end{array}$ & Uncooled microbolometer $/ 7.5-14 \mu \mathrm{m}$ \\
\hline Operating temperature range & $\begin{array}{c}-40^{\circ} \mathrm{C} \text { to }+150^{\circ} \mathrm{C}\left(-40^{\circ} \mathrm{F} \text { to } 302^{\circ} \mathrm{F}\right) \\
+100^{\circ} \mathrm{C} \text { to }+650^{\circ} \mathrm{C}\left(+212^{\circ} \mathrm{F} \text { to } 1202^{\circ} \mathrm{F}\right)\end{array}$ \\
\hline Laser alignment & Position is automatic displayed on the IR image \\
\hline
\end{tabular}

\section{Results and discussion}

Three technologies of the PV modules were examined (pc-Si, CdTe and CIGS) in order to find the working temperature of the modules and possible faults that can lead to a decrease of energy production. Fig. 2 shows the temperature distribution of the pc-Si module under high irradiance conditions. Uniform color distribution of the module surface indicates an equal working temperature of adjacent solar cells. Average temperature measured was 
found to be $39^{\circ} \mathrm{C}$. As it was shown in Fig. 3, the temperature profile measured for the pc-Si module confirmed this value.

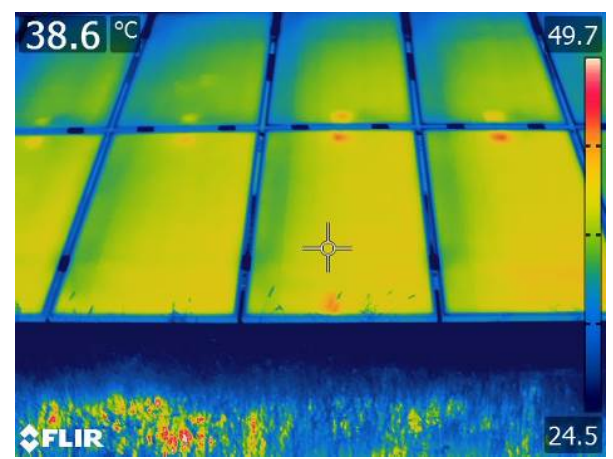

Fig. 2. Temperature distribution of $\mathrm{pc}-\mathrm{Si}$ modules measured by FLIR system.

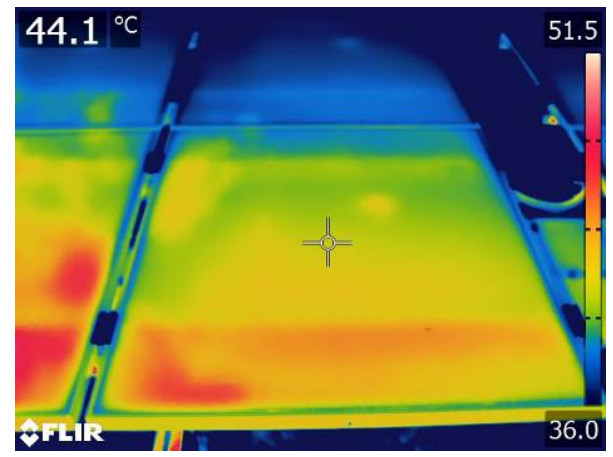

Fig. 4. Temperature distribution measured for CIGS module.

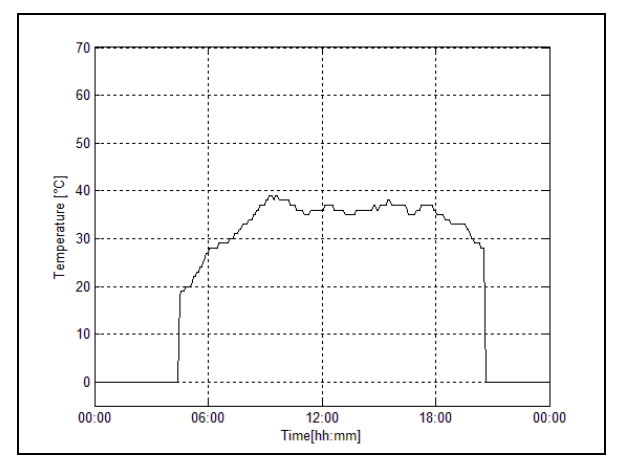

Fig. 3. Temperature profile of the module during sunny day with high irradiance level.

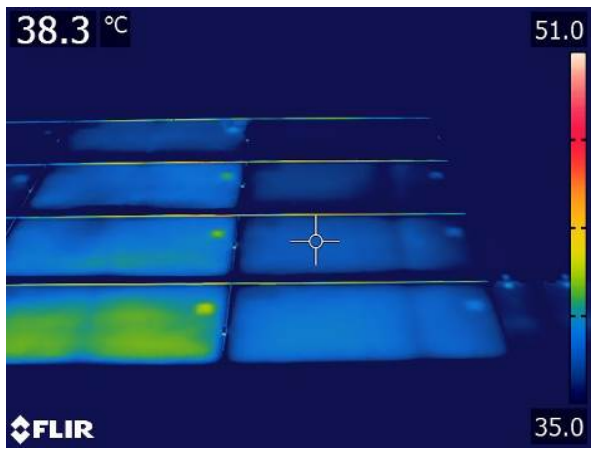

Fig. 5. Temperature distribution measured for CdTe modules.

Figs. 4-5 show the results of temperature measurements for CIGS and CdTe modules. As it can be seen, thin film devices work under similar temperature range as pc-Si. The average temperature of the CIGS and CdTe module was found to be $45^{\circ} \mathrm{C}$ and $38^{\circ} \mathrm{C}$ respectively.

Most of the modules examined in Zielawa Valley power plant were characterised by uniform temperature distribution. However, it was possible to find example of devices with non-uniform temperature distribution. Fig. 6 shows pc-Si module in which one of the solar cell works with higher temperature in comparison to others cells. The temperature difference is small (a few degrees) but it can indicate the beginning of problems with this module. A more serious fault was found in the CIGS module. As it can be seen in Fig. 7, a point defect causes a higher working temperature in this area of the surface. The temperature difference is about $10^{\circ} \mathrm{C}$ in comparison to the rest of the module. 


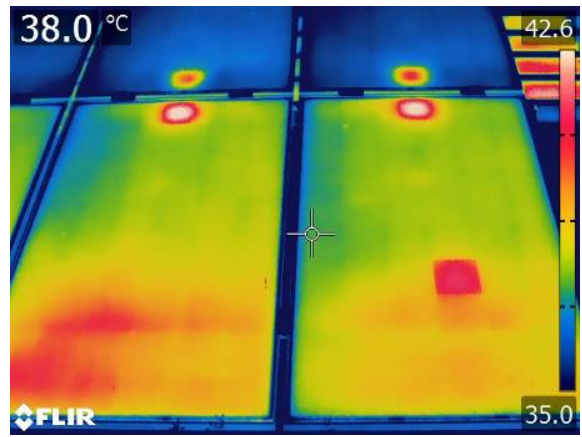

Fig. 6. Example of pc-Si module with a single solar cell of higher working temperature.

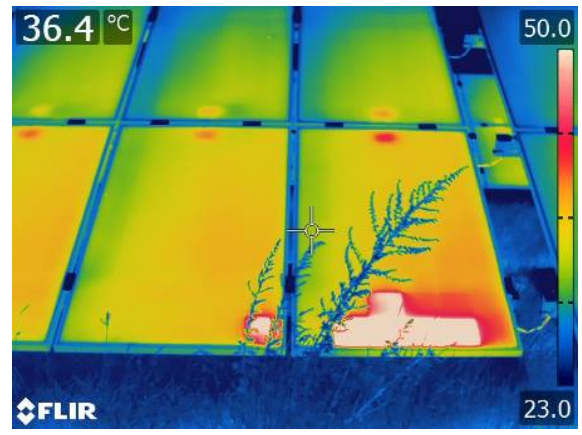

Fig. 8. Overheated solar cells of the module due to shadowing by plants.

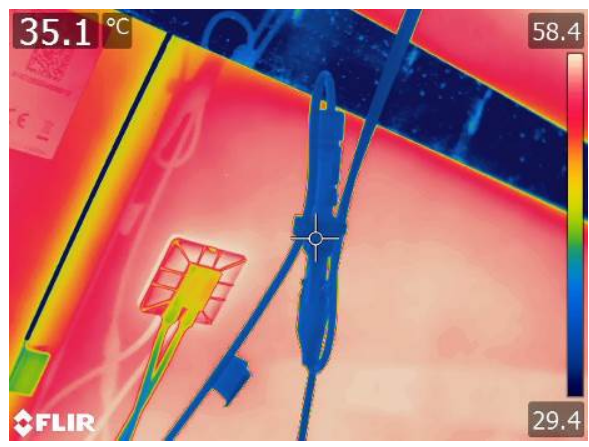

Fig. 10. Normal working temperature of MC4 connector $\left(35^{\circ} \mathrm{C}\right)$.

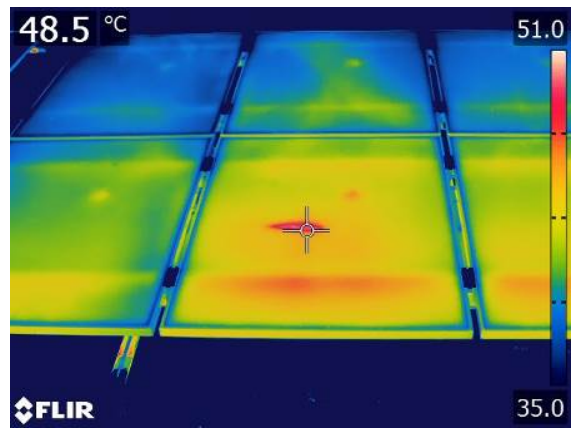

Fig. 7. Higher working temperature of point defect detected in CIGS module.

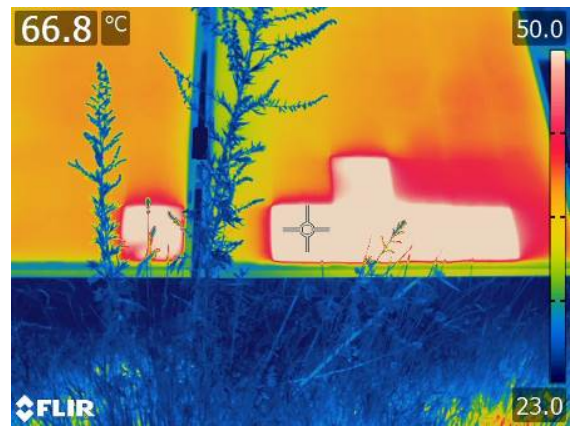

Fig. 9. Temperature measurement of overheated cells caused by local shadowing.

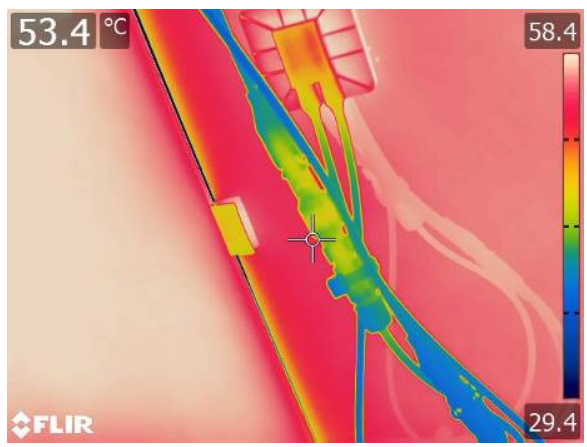

Fig. 11. Overheating occurred due to poor contact inside connector.

Probably one of the biggest and most common problems with the PV systems is partial shading of the module surface, for example by plants. Fig. 8 shows an example of the module for which the working temperature was uniform. However, shadowing cells were characterised by a higher temperature (close to $70^{\circ} \mathrm{C}$ ) which can be very dangerous for the module in terms of hot-spot phenomena (Fig. 9). The temperature of the cells partly shadowed by plants can reach even more that $100^{\circ} \mathrm{C}$.

Components of PV installation such as connectors were also under examination. Fig. 10 shows that the typical temperature of a MC4 connector under load was found to be $35^{\circ} \mathrm{C}$. Overheated connectors were also found. Fig. 11 shows the temperature measurement of 
an overheated connection caused by poor contact. As it can be seen, the temperature observed in this case was about $53^{\circ} \mathrm{C}$. It can reveal problems inside the connector that can lead to energy losses, breaks in the circuit or even fire.

It should be emphasized that all issues discussed above have confirmed the high importance of IR-examination in terms of failure detection to avoid permanent damage of the PV installation.

\section{Conclusions}

Infrared thermography analysis of a large power plant located in east Poland was carried out under high irradiance conditions. Different module technologies were investigated: pc-Si, CIGS, CdTe. Temperature distribution of PV modules as well as MC4 connectors were examined in order to find overheated areas that can be dangerous for particular devices. The working temperature of the modules was found and confirmed by measured temperature profile. As it was shown, the surface temperature of the modules was in the range of $38-45^{\circ} \mathrm{C}$ during the measurements.

Presented results confirm that IR-thermography is a relatively fast method which allows finding faults existing inside the modules or caused by local shading. Examination of the module temperature distribution can reveal non-uniformities that indicate problems which have to be eliminated to assure the long life of the PV system. What is more, avoiding local shadowing caused mostly by plants or bird droppings seems to be crucial in daily maintenance procedure. As it was shown, local shadowing can lead to a temperature rise of the cell up to $70^{\circ} \mathrm{C}$. Finally, overheating that occurred due to poor contact inside the connector was also detected. The normal working temperature of the connector was found to be $35^{\circ} \mathrm{C}$, however the temperature of the overheated one was about $20^{\circ} \mathrm{C}$ higher.

\section{References}

1. J. Solórzano, M.A. Egido, Ener. Convers. Manage. 76, 925-934 (2013)

2. IEA. (Analysis of photovoltaic systems. In: Report: T2-01:2000, International

3. Energy Agency,2000)

4. IEA. (Country reports on PV system performance. In: Report T2-05:2004,

5. International Energy Agency, 2004)

6. E. Lorenzo, R. Moretón, I. Luque, Progr. Photovolt. Res. Appl. 22, 666-670 (2014)

7. J. Muñoz, E. Lorenzo, F. Martinez-Moreno, L. Marroyd, M. Garcia, Progr. Photovolt. Res. Appl. 16, 693-701 (2008)

8. S. Deng, Z. Zhang, C. Ju, J. Dong, Z. Xia, X. Yan, T. Xu, G. Xing, Energy Procedia 130, 77-86 (2017)

9. Z. Zhang, L. Wang, Acta Energiae Solaris Sinica 37, 355-360 (2016)

10. M. Simon, E. L. Meyer, Sol. Energ. Mat. Sol. C. 94, 106-113 (2010)

11. P. Rajput, G.N. Tiwari, O.S. Sastry, Sol. Energy 139, 569-580 (2016)

12. R. Moreto, E. Lorenzo, L. Narvarte, Sol. Energy 118, 28-40 (2015)

13. S. Gułkowski, E. Krawczak, E3S Web Conf. 1903006 (2017)

14. E. Krawczak, S. Gułkowski, E3S Web Conf. 1903011 (2017)

15. E. Krawczak, A. Zdyb, S. Gulkowski, A. Fave, E. Fourmond. E3S Web Conf. 2200090 (2017)

16. P. Billewicz, P. Węgierek, T. Grudniewski, Prz. Elektrotechniczn. 93, 180-183 (2017) 
17. T. Grudniewski, Journal of Civil Engineering, Environment and Architecture 63, 177-184 (2016)

18. J. A. Tsanakas, LongHa, C. Buerhop, Renew. Sust. Energ. Rev. 62, 695-709 (2016)

19. C. Buerhop, D. Schlegel, M. Niess, C. Vodermayer, R. Weißmann, C.J. Brabec, Sol. Energ. Mat. Sol. C. 107, 154-164 (2012)

20. T. Kaden, K. Lammers, H. J. Möller, Sol. Energ. Mat. Sol. C. 142, 24-28 (2015)

21. T. Kaden, K. Lammers, S. Hoffmann, M. Köhl, P. Bentz, H.J. Möller, Proceedings of the 29th European Photovoltaic Solar Energy Conference, 2994-2996 (2014)

22. J. Olchowik, S. Gulkowski, K. Cieslak, J. Banas, I. Jozwik, D. Szymczuk, K. Zabielski, J. Mucha, M. Zdrojewska, J. Adamczyk, R. Tomaszewski, Mater. SciPoland 24, 1127-1132 (2006)

23. W. Grzesiak, P. Mackow, T. Maj, A. Polak, E. Klugmann-Radziemska, S. Zawora, K. Drabczyk, S. Gulkowski, P. Grzesiak, Sol. Energy 132, 442-452 (2016)

24. P. Dragan, A. Zdyb. J. Ecol. Eng. 18, 231-235 (2017)

25. www.renesola.com/product/solar (access 26.04.2018)

26. https://www.solar-frontier.eu/en/download/products (access 26.04.2018)

27. https://calyxo.com/en/cx-series.html (access 26.04.2018)

28. http://www.flir.eu (access 26.04.2018) 